Cornell Law Library Scholarship@Cornell Law: A Digital Repository

Cornell Law School Inter-University Graduate

Student Conference Papers

Conferences, Lectures, and Workshops

4-14-2009

\title{
Does One Size Fit All? A Comparative Study to Determine an Alternative to International Patent Harmonization
}

Rohan K. George

Columbia Law School

Follow this and additional works at: http://scholarship.law.cornell.edu/lps_clacp

Part of the Intellectual Property Commons, and the International Law Commons

\section{Recommended Citation}

George, Rohan K., "Does One Size Fit All? A Comparative Study to Determine an Alternative to International Patent Harmonization" (2009). Cornell Law School Inter-University Graduate Student Conference Papers. Paper 28.

http://scholarship.law.cornell.edu/lps_clacp/28 
Does One Size Fit All? A Comparative Study to Determine an Alternative to International Patent Harmonization

by

\author{
Rohan. K. George \\ (Columbia Law School)
}




\section{Introduction}

The Agreement for Trade Related Aspects of Intellectual Property Rights (TRIPS) was ratified by a majority of the countries of the world in 1994 as a precondition to membership in the World Trade Organization. Today, 153 of the countries of the world are parties to the TRIPS Agreement. The effect of the TRIPS Agreement was to create the first international substantive standards of patent harmonization, and to cause many countries to adopt intellectual property laws far stronger than they had in existence at the time. Today, the process of patent harmonization initiated with the TRIPS Agreement moves forward, through a combination of multilateral discussions for a Substantive Patent Law Treaty and bilateral treaties and negotiations incorporating stronger standards of intellectual property protection than those implemented under the TRIPS Agreement.

Whether this process of international adoption of stronger patent standards is beneficial to all countries involved is a question that has dominated the international patent debate since the TRIPS Agreement. Many developing countries have protested having to adopt stronger patent protection measures, and public health and access to medicine concerns caused by the rising prices of patented pharmaceuticals dominate the discourse around the TRIPS Agreement. All of these factors beg the question: Does a 'one size fit all' policy of international patent harmonization make sense to all countries equally?

From the experience of the United States, it appears that a strong patent system can be beneficial to the economic and industrial development of a country. However, the experiences of other countries has shown that stronger standards can even retard economic growth, instead of benefitting it. The purpose of this paper is to examine the economic and historic justifications of the worldwide shift towards stronger patent laws. In doing so, it also seeks to determine whether there is a case to be made for the alternative, a shift towards discrete levels of patent protection, where countries choose patent laws according to their economic, social and industrial needs, and not according to an externally dictated process of standardization. 
The first part of my paper examines the history of patent harmonization, and current efforts to extend the process of harmonization further. The second part asks whether there is a stronger argument for each country to take its own discrete stand on its patent laws instead of staying on the harmonization bandwagon. In doing this, it examines examples from the histories of some major developing countries, as well as the history of patent law in the developing country experience. It also analyses the economic benefits of patent harmonization versus a discrete patent system. The third part of this paper compares the patent systems of India and the United States, two countries with distinct approaches to the use of intellectual property, and determines the extent to which the unique features of each benefit them. 


\section{The History of International Patent Harmonization}

\section{Multilateral Efforts Towards Harmonization}

Given the dependence of any patent regime upon administrative systems, it is not surprising to note that the process of international patent harmonisation began with the Paris Convention and an international commitment to respect filing dates for patent applications - a predominantly procedural commitment. Of equal importance, however, was the commitment of each signatory country to provide equivalent treatment under national patent laws to citizens of all other signatory countries, a step which established the groundwork for an international market for patents ${ }^{1}$.

The first step towards substantive harmonisation of patent laws, however, was not to come until a century later, with the WIPO's failed attempt to create a 'Treaty Supplementing the Paris Convention as far as Patents are Concerned' (Old Patent Harmonization Treaty') ${ }^{2}$. Discussions concerning the treaty, however, broke down in 1992 with key disagreements between developed and developing countries, as well as within the developed countries themselves. An important factor contributing to the breakdown of negotiations was the United States' refusal to accept the 'first-to-file' requirement proposed under the treaty ${ }^{3}$. The provisions of the draft treaty, however, were important in that they laid down a foundation for the creation of parameters for patent harmonization such as the creation of conditions of patentability ${ }^{4}$ and the applicability of patent protection to all fields of technology ${ }^{5}$.

1 Paris Convention for the Protection of Industrial Property, arts. 2 and 4, March 20, 1883, http://www.wipo.int/export/sites/www/treaties/en/ip/paris/pdf/trtdocs_wo020.pdf

2 Diplomatic Conference For the CONCLUSION OF A TREATY SuPPLEMENTING THE PARIS CONVENTION AS Far AS PATENTS ARE CONCERNED \& WORLD INTELLECTUAL PROPERTY ORGANIZATION, RECORDS OF THE DiPlOMATIC Conference for the Conclusion Of a Treaty Supplementing the Paris Convention as Far as Patents Are CONCERNED 629 (1991)

3 CORREA, CARLOS (2005), AN AGENDA FOR PATENT REFORM AND HARMONIZATION FOR DEVELOPING COUNTRIES, PAPER

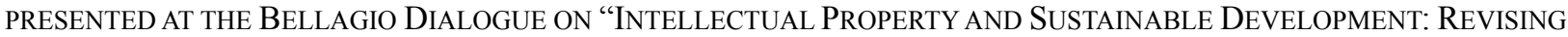
THE AGENDA IN A NEW CONTEXT”, ICTSD, 24 - 28 SEPTEMBER 2005, Bellagio, ITALy, AVAILABle AT www.ictsd.org, P. 2

4 Treaty Supplementing the Paris Convention as Far as Patents Are Concerned, Art. 11, Supra note 2. at 2; IdId. at 21 
The entry into force of the TRIPS Agreement in 1994 marked the first step in true substantive harmonisation of patent laws. Many of the provisions of the Old Patent Harmonization Treaty were utilised in the TRIPS Agreement, including the articles relating to patentable subject matter, conditions on patent applicants and term of the patent ${ }^{6}$. The TRIPS Agreement laid down minimum standards required to be followed by all WTO member states in their national patent laws, and did not prevent the adoption of higher patent standards, if so desired ${ }^{7}$.

Though the TRIPS Agreement is considered the strongest example of substantive harmonization of patent law, it does not mark the end of the process. In 2001, the WIPO launched a Patent Agenda in order to make the process of international patent protection 'yet more user-friendly, cost-effective and secure. $^{8}$ As part of the Patent Agenda, the WIPO developed the Substantive Patent Law Treaty (SPLT), a proposed treaty aimed to focus on issues of relevance to the grant of patents, such as the definition of prior art, novelty, inventive step/non-obviousness, industrial applicability/utility, the drafting and interpretation of claims and the requirement of sufficient disclosure of the invention ${ }^{9}$. The SPLT is considered to be an attempt towards 'deep harmonization' of the substantive aspects of patent law and practice ${ }^{10}$, with the aim of travelling far beyond the minimum requirements laid down in the TRIPS Agreement, with firmer commitments on substantive aspects of patent law. Discussions concerning the SPLT are currently under way, with the Thirteenth Session of the Standing Committee

5 Treaty Supplementing the Paris Convention as Far as Patents Are Concerned, Art. 10; Id. at 20Id. at 20

6 AgreEment on Trade-Related AspeCts of Intellectual Property Rights [TRIPs], ANNEX 1C TO the MARRAKESH AgreEMENT Establishing THE WORLd TRAde ORGANIZATION, 15 APril 1994, ARTS. 27, 29 AND 33

7 Id., Art. 1(1)

8 Memorandum of the Director General, WiPO document A/36/14, ‘Agenda for DeVelopment of the INTERNATIONAL PATENT SYSTEM', 6 AUgust 2001, GENEVA, AT http://www.wipo.int/edocs/mdocs/govbody/en/a 36/a 36 14.pdf, PARA 3

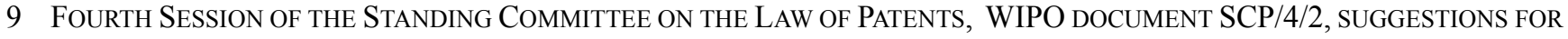
THE FURTHER DEVELOPMENT OF INTERNATIONAL PATENT LAW, 25 SEPTEMBER, 2000, GENEVA, 3, http://www.wipo.int/edocs/mdocs/scp/en/scp_4/scp 4 2.pdf

10 Jerome H. REICHMAN \& ROCHELlE DREYFUSS, HARMONIZATION Without CONSENSUS: CRITICAL REFLECTIONS ON DRAFTING A SUBSTANTIVE PATENT LAW TREATY, SSRN ELIBRARY, 90, http://papers.ssrn.com/sol3/papers.cfm?abstract_id $=1028331$ 
on the law of Patents (SCP) convening on March $23^{\text {rd }}, 2009^{11}$.

The SPLT is still far ahead in the horizon, and the current state of the art of multilateral patent harmonization lies within the TRIPS Agreement. However, the protections afforded by the TRIPS Agreement have been found insufficient by a number of developed countries, which seek to pursue higher standards of patent harmonization through bilateral negotiations.

\section{Bilateral Harmonization Efforts}

While the standards of patent protection required by the TRIPS Agreement were higher than those earlier adopted by many developing countries, they were nevertheless weaker than those accepted by the developed countries. With the surge in international trade in goods and knowledge, the need was felt for stronger standards than those afforded under the TRIPS. By utilising the flexibilities allowed under the TRIPS Agreement for countries to adopt higher standards than those specified in the agreement, the US and the EU sought to strengthen these standards through bilateral negotiation. Since 1994, the United States and the European Union have entered into a number of free trade agreements with a number of developing countries, incorporating higher standards of intellectual property protection as conditions to these agreements. The US-Chile FTA requires Chile to propose legislation making available patent protection for plants ${ }^{12}$ even though the TRIPS Agreement permits the exclusion of such provisions ${ }^{13}$. Similar provisions are reflected in the US-Morocco FTA and the USBahrain FTA $^{14}$. Other clauses utilised in other US FTAs limit the ability of countries to use compulsory

11 THE PAPERS OF THE THIRTEENTH SESSION AS PRODUCED SO FAR ARE AVAILABLE AT http://www.wipo.int/meetings/en/details.jsp?meeting id $=17448$

12 United States-Chile Free Trade Agreement, 2003, ArT. 17.9:2, http://www.ustr.gov/Trade_Agreements/Bilateral/Chile_FTA/Final_Texts/Section_Index.html

13 SUPRA NOTE 6, ART. 27.3(B)

14 United States-Morocco Free Trade Agreement, 2004, Art. 15.9:2, http://www.ustr.gov/Trade_Agreements/Bilateral/Morocco_FTA/Section_Index.html ; UNITED STATES-BAHRAIN FREE TRADE AGREEMENT, 2003, ART. 14.8.1, http://www.ustr.gov/Trade_Agreements/Bilateral/Bahrain_FTA/Section_Index.html 
licensing provisions ${ }^{15}$, revocation of patents $^{16}$ and other aspects of patent regulation. While these treaties and those entered into by the European Union are bilateral in nature, they have been entered into with a large number of countries, with the result that they constitute a process of harmonization in themselves. The proliferation of such free trade agreements or Bilateral Investment Treaties (BITs) represent a process that sees the rapid globalisation of the intellectual property norms propogated by their supporters ${ }^{17}$. They also ensure that the developing countries that enter into them are integrated into international regimes of intellectual property protection far beyond those envisaged by existing standards such as the TRIPS Agreement ${ }^{18}$. In addition to this, these treaties also require these developing countries to comply with multilateral standards in conventions to which they are not a party, or to ratify international IP treaties which they have no obligation to comply with ${ }^{19}$, thereby increasing the standard of intellectual property compliance worldwide.

15 United States-Singapore Free Trade AgreEMENT, 2003, ART.16.7:6, http://www.ustr.gov/Trade_Agreements/Bilateral/Singapore FTA/Section_Index.html

16 SUPRA NOTE 12, ART. 17.9:5; SUPRA NOTE 15, ART. 15.9:4; SUPRA NOTE 14, ART. 14.8:4

17 Drahos Peter; DeVeloping Countries and International InTEllectual Property Standard-Setting; Study PREPARED FOR THE UK COMMISSION ON INTELLECTUAL PROPERTY RIGHTS, 2002; AVAILABLE AT http://www.iprcommission.org, p. 22

18 ID AT P. 22

19 For eXAmple, SeE ARTicle 4.1 AND 4.29 of THE Unites States-Jordan FTA, 2000, http://www.ustr.gov/Trade_Agreements/Bilateral/Jordan/Section_Index.html 


\section{The Argument for Diversity in National Patent Laws}

Today, we live in a world where patent sytems are increasingly harmonized, with almost all national patent regimes moving towards conformity with the TRIPS Agreement, and many moving beyond. However, there is a strong need to examine whether such a system of international patent harmonization that requires many parties to move towards stronger patent laws is beneficial for all parties. Although a number of studies have established a relationship between strong intellectual property regimes and economic growth ${ }^{20}$, others have determined that intellectual property regimes are actually detrimental to such growth ${ }^{21}$. It is proposed that one of the primary reasons for this apparent conflict concerning the effects of strong patent systems is founded upon an assumption that such effects would apply consistently across countries with vastly different economic, cultural and developmental backgrounds. Existing approaches to international intellectual property standard-setting follow the 'one size fits all' policy of creating a unified system of strong patent protection for all countries. However, a variety of historical, economic and social factors show, to the contrary, that such a unified approach towards intellectual property policy is not merely lacking in benefits towards certain countries, but may be detrimental towards them as well.

\section{Historical Arguments for Patent Diversity}

It has been noted that one of the reasons for the rapid increase in manufacturing productivity in the United States was a strong patent system, and its careful evolution to fit the needs of the American economy $^{22}$. However, it has also noted that the creation of a system was the result of a deliberate and

20 David M. Gould \& William C. Gruben, The role of intellectual property rights in economic growth, 48 JOURNAL OF DEVELOPMENT ECONOMICS 323-350 (1996)

21 MASKuS, KeIth. E.; SYMPOSIUM:TAKING STOCK: THE LAW AND ECONOMICS OF INTELLECTUAL PROPERTY RIGHTS: LESSONS FROM STUDYING THE INTERNATIONAL ECONOMICS OF INTELLECTUAL PROPERTY RIGHTS; 53 VAND. L. REV 2219, 2222

22 KHAN, ZORINA B.; INTELLECTUAL PROPERTY AND ECONOMIC DEVELOPMENT: LESSONS FROM AMERICAN AND EUROPEAN HISTORY; STUDY PREPARED FOR THE UK COMMISSION ON INTELLECTUAL PROPERTY RIGHTS, 2002; AVAILABLE AT 
conscious process of tailoring to suit the national interest ${ }^{23}$. Similarly, the patent systems of the States comprising European system were also created by a similar system of customisation towards the specific needs of their countries at specific times ${ }^{24}$. The patent systems of most developing countries, however, are largely the legacy of colonial policy and empire-building ${ }^{25}$. Patent laws were imposed on colonies such as Malaysia, the Philippines, Korea and India, and retained subsequent to their liberation $^{26}$. Upon gaining independence, many of these countries began to customise their patent systems in order to reflect their own economic and industrial interests. Accordingly, a number of them, such as India, Brazil, Argentina and Mexico began to lower standards in order to provide breathing room for rapidly developing generic pharmaceutical industries ${ }^{27}$. In India, in particular, the rapid evolution of the Indian pharmaceutical industry was facilitated by a major change in India's patent laws in 1970, reducing the scope of patentablility in food, chemicals and pharmaceuticals to processes of manufacture instead of products, with a simultaneous reduction in the term of protection granted to such patents ${ }^{28}$. The connection between the growth of this industry and the relatively weaker patent protections afforded by India's change in patent policy was evident ${ }^{29}$. This process of customisation, in India and in other countries, was widely criticised by countries with strong intellectual property regimes, and was one of the factors that prompted the United States and the US big business community to lobby for the inclusion of the TRIPS Agreement in the Uruguay Trade Round of the GATT $^{30}$. However, it is important to note that the history of patent policy worldwide indicates a pattern similar to that followed by the developing countries.

http://www.iprcommission.org, , 20

23 ID AT 21

24 ID AT 4

25 SUPRA NOTE 17 AT 7

26 ID AT 8

27 ID AT 9

28 Kumar, NAgesh, INTELLECTUAL PROPERTy RIGHTS, TECHNOLOGY AND ECONOMIC DEVELOPMENT: EXPERIENCES OF ASIAN Countries; STUdy PREPARED FOR THE UK COMMISSION ON INTELLECTUAL PROPERTy Rights, 2002; AVAILABLE AT http://www.iprcommission.org, 27

29 Kumar, NAGESH AND MOHAMMED SAqIB (1996) FIRM SiZE, OPPORTUNITIES FOR ADAPTATION AND IN-HOUSE R\&D ACtIVITY In DEVELOPING COUNTRIS: THE CASE OF INDIAN MANUFACTURING; RESEARCH POLICY; 25(5): $712-22,719$

30 SSusan K Sell, Intellectual Property Protection and Antitrust in the Developing World: Crisis, Coercion, and Choice, 49 INTERNATIONAL ORGANIZATION 315-49 (1995) 
Historical analyses of various patent systems have yielded the conclusion that a number of developed countries had, at different times, adopted patent systems with weaker levels of protection in order to promote the growth of fledgeling technology-dependent industries $\quad 31$. One example of this involves the United Kingdom, which changed its patent laws between 1919 and 1949 in order to exclude chemical products from patent production in order to ward off the threat posed by the German chemical industry and which allowed for a system of licenses of right until 1977, allowing British manufacturers to compel foreign patentees to permit the use of their patents on pharmaceuticals and food products ${ }^{32}$. In addition, patent protection for medicines was excluded under French and Japanese patent laws until recently ${ }^{33}$. This diversity in patent law was, by no means, reduced in the last century, with a study by the WIPO in 1988 demonstrating that of the 98 members of the Paris Convention, 49 excluded product patent protection for pharmaceuticals, 45 excluded animal varieties, 44 excluded plant varieties and 22 excluded chemical products ${ }^{34}$.

\section{Economic Arguments for Patent Diversity}

In order to determine an economic argument for patent diversity, it is important to understand the underlying benefits granted by a patent system. However, prior even to that, it is important to understand the basic assumptions made in evaluating such benefits. The first such assumption is that society needs more inventions than would be made if society did not offer an incentive to invent. The second assumption is that the best such incentive is the exclusivity provided by the patent system ${ }^{35}$.

31 Moser, Petra, How Do PATENT LAWS InFLUENCE INNOVATION? EVIDENCE FROM NiNETEENTH-CENTURY WorLD'S FAIRS, 95 THE AMERICAN ECONOMIC REVIEW 1214-1236, 1231 (2005)

32 SUPRA NOTE 22 AT 14

33 Id at 16,28

34 WIPO, EXISTENCE, SCOPE AND FORM OF GENERALLY INTERNATIONALLY ACCEPTED AND APPLIED STANDARDS/NORMS FOR THE PROTECTION OF INTELLECTUAL PROPERTY; MTN.GNG/NG11/W/24/REV.1; 15 SEPTEMBER 1988; http://www.tripsagreement.net/documents/GATTdocs/erally_Internationally_Accepted_and_Applied_Standards_\&_Nor ms for the Protection_of_IP__Revision_E_E.pdf 
These assumptions, as stated, have not necessarily met with unanimous acceptance ${ }^{36}$. However, on the basis of their acceptance lies the foundation of the patent system, and the benefits associated with it. The primary benefit derived from the patent system consists of those benefits derived from inventions that would not have been made but for it. It is assumed by some that many inventions that constitute a genuine revolution in production or consumption patterns are patent-induced, requiring, as they do, large investments and high risks of failure $\quad 37$.

Ranged against this benefit are a number of costs that may accrue to a country from having a patent system. Donald Turner had listed seven cost elements that may be attributed to a patent system ${ }^{38}$. They are listed as follows:

i. Administrative costs

ii. The underutilisation of inventions that have obtained protection under the patent system but would have been produced without a patent system

iii. losses from the abuse of the patent monopoly, including antitrust violations, term extension and patent misuse

iv. research expenditures undertaken by competitors in attempting to avoid the patent rights owned by others

v. losses incurred as a result of investments in patents in non-innovative products in order to preclude competitors from marketing those inventions, with no intention to market or produce such inventions themselves (patent trolling)

vi. the inhibition of inventive activity in areas heavily covered by the patents of competitors (the patent thicket problem)

vii. The apparent over-allocation of resources to applied research over basic research, with

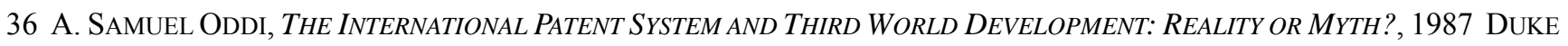
LAW JOURNAL 831-878, 837 (1987).

37 F. M. SCHERER, INDUSTRIAL MARKET STRUCTURE AND ECONOMIC PERFORMANCE 448 (1970)

38 Supra note 35 at 454 
inventors foregoing allocation of resources for basic research in favour of more the more profitable returns from the patent monopoly.

These benefits and costs play against each other to varying degrees in most developed country patent systems. The decisions of these countries to promote and strengthen their systems of patent protection indicates benefits outweighing costs in such systems.

However, decisions concerning the benefits and costs of a patent system in a developing country require a rethinking of the underlying assumptions concerning these benefits and costs. In addition to the abovementioned assumptions of the patent system (i.e. those concerning society's needs for inventions that would not be created without an incentive for invention and that the best such incentive is offered through the patent system)an additional assumption is required for a patent system to function within a developing country: that the grant of patents on such inventions will lead to development $^{39}$. Due to the specific problems of developing countries, they are more in need of technologies that would improve the standards of existing and nascent industries and promote development, as opposed to those that would revolutionise ${ }^{40}$. The implication of this is that the former two assumptions concerning the patent system may require further scrutiny in the light of the latter.

In addition to problems concerning the basic assumptions underpinning a patent system, it is important to face the reality of the international patent system as applied to developing countries, namely, that the majority of patents granted in developing country patent systems are granted to foreigners $\quad 41$. Given this reality, it is important to understand that the existence of a patent system within such a developing country would serve less to promote new inventions within that country than to extend protection to inventions developed in other countries, and sought to be utilised within the developing

39 SUPRA NOTE 36 AT 843

40 ID. AT 844

41 Sun, YifEI, DETERMinANTS OF FOREIGN PATENTS IN CHINA, 25 WORLD PATENT INFORMATION 27-37 (2003); MATTHEWS, DunCAN, Globalising InTELLECTUAL PROPERTY Rights 202 (2002); CHEN, EdWARD K. Y. ET AL., TECHNOLOGY TRANSFER TO DEVELOPING COUNTRIES 486 (1994) 
country $^{42}$. As a result of this, developing countries would find that developmental benefits associated with a particular invention would be easier to obtain without the patent system than with it, and that, due to the list of costs associated with a patent system, the most cost-effective manner of obtaining benefits from an invention would be to reduce or free itself of restraints imposed upon itself by the patent system. This is the realisation arrived at by the newly independent colonies in lowering their patent standards to promote fledgeling industries and to encourage reverse-engineering ${ }^{43}$. An analysis of the history of patent law worldwide would support this assertion, with the experiences faced by developed countries in the evolution of their patent systems when they were at a lower state of development. 


\section{Comparative Study of Selected Factors of Patent Law and Regulation}

An understanding of the benefits of tailoring patent regimes to suit country interests would be helped by a comparison of different countries and their patent regimes. Within the analysis of countries presented by Maskus by intellectual property usage and preference of intellectual property regime, the

United States would be considered an IP exporter ${ }^{44}$, with high levels of production and sale of intellectual property and an interest in strong international rights. India, on the other hand, would be considered an IP follower ${ }^{45}$, an industrialising economy which needs access to inexpensive and readily diffused access to modern technology, and a mixed interest, situated between encouraging incoming technology flows and weak standards to promote imitation and learning. A comparison of their patent regimes shows that, as far as possible within the standards established by international patent harmonisation, the patent laws of the US and India reflect the interests specific to their utilizations of intellectual property.

\section{The Indian Patent Act, 1970}

Patent laws in India have been in existence since the time of the British colonization. The Patents and Designs Act had been passed in 1911, and continued to be in force after India achieved independence in 1947. However, the act was reformed in 1970, after successful lobbying efforts by India's nascent pharmaceutical industry ${ }^{46}$. The new Patents Act, 1970 reduced the scope of patentability in food, chemicals and pharmaceuticals, limiting patent protection for these categories to process protection instead of product protection. With India's ratification of the TRIPS Agreement, India was required to amend its patent laws in 1999, 2002 and again in 2005. The current version of the Indian Patents Act provides product protection to all categories of invention, but with strong limitations upon the scope of

44 Supra note 21, p. 2

45 Id, p. 2

46 Supra note 28 , p. 27 
such protection.

\section{Substantive Provisions: Comparison between India and the United States}

\section{$\underline{\text { Patentable Subject Matter }}$}

India: Some of the most significant substantive provisions of the Indian Patent Act, 1970 deal with the scope of patentable subject matter. As was mentioned earlier, product protection for pharmaceuticals, chemicals and food products was provided under the 2005 Act. However, these provisions were tempered by the introduction of Section 3(d) into the Act, which denied protection to new forms, properties or uses of known substances which did not enhance efficacy ${ }^{47}$. Other provisions of the Act deny protection to plants, animals and essentially biological processes of their production or propogation $^{48}$, business methods and computer programs per se $e^{49}$ and mental acts or methods ${ }^{50}$.

The United States: US patent laws provide much broader grounds for patentability, allowing for the patenting of new and useful processes, machines, manufactures or compositions of matter, or new and useful improvements thereof ${ }^{51}$. US Courts have interpreted this provision to allow for the patenting of new life forms ${ }^{52}$, computer software ${ }^{53}$ and business methods ${ }^{54}$. However, the scope of patentability of business methods and computer software has been limited somewhat in recent Supreme Court decisions $^{55}$.

\section{Qualifications for Invention: Novelty, Utility and Obviousness}

In addition to patentable subject matter, the Indian Patent Act also provides more stringent statutory

47 The Patents Act, 1970, Section 3(d)

48 Id, Section 3(j)

49 Id, Section 3(k)

$50 \mathrm{Id}$, Section 3(m)

5135 U.S.C. $\$ 101$

52 Diamond v. Chakrabarty, 447 U.S. 303 (1980)

53 In re Alapatt, 33 F.3d 1526 (Fed. Cir. 1994)

54 State Street Bank \& Trust Co. v. Signature Financial Group, Inc., 149 F.3d 1368 (CAFC 1998)

55 In re Bilski, 545 F.3d 943, (Fed. Cir. 2008) 
requirements for novelty, obviousness and utility. The Act requires that patents may only be granted to inventions, and an invention is defined as a new product or process involving an inventive step and capable of industrial application ${ }^{56}$.

\section{Utility}

India: The utility requirement in India corresponds to the requirement for 'industrial application', which, unlike the US requirement for utility, requires that an invention be capable of being made or used in an industry ${ }^{57}$. In interpretation, however, Courts have agreed that the parameters of an invention 'being made or being used in an industry' are broad.

United States: In the United States, the utility requirement is more liberal, allowing for the patenting of an invention as long as it 'is useful' ${ }^{58}$. This requirement has been interpreted by US Courts as indicating that the invention must have some specific utility, and that such utility be disclosed at the time of patenting $^{59}$. Beyond these limitations, however, the utility requirement is limited.

\section{Obviousness}

India: The obviousness requirement corresponds to the 'inventive step' requirement, which was modified in 2005. The new inventive step clause requires the invention to have a feature that involves a technical advance compared to existing knowledge or economic significance, either or both of which should make the invention non-obvious to a person skilled in the $\operatorname{art}^{60}$.

The United States: The non-obviousness requirement in US law declares that an invention is to be considered obvious if the an analysis of the differences between the subject matter and the prior art show that the subject matter as a whole would have been obvious at the time the invention was made to

$56 \quad$ Supra note 47 , Section $2(\mathrm{j})$

57 Id, Section 2(ac)

58 Supra note 51

59 In re Brana, 51 F.3d 1560 (CAFC 1995)

$60 \mathrm{Id}$, Section 2(ja) 
a person having ordinary skill in the art ${ }^{61}$. The analysis of the obviousness requirement under US patent law has been detailed, and the creation of a number of formal tests and indicators of obviousness have somewhat restricted the scope of usage of this provision. Recently, however, US Supreme Court reversed the reliance on formal tests such as the Teaching-Suggestion and Motivation test and reinstated a broader analysis of obviousness ${ }^{62}$.

\section{Novelty}

India: The novelty requirement corresponds to the 'new invention' clause in the Act, which requires that the invention has not been anticipated by publication or use anywhere in the world prior to the filing of the patent application ${ }^{63}$.

United States: A significant difference between US and Indian patent laws lies in the fact that the US novelty requirement requires that the patent not be known or used by others within the US, but only that it not be patented or described in a printed publication in any other country ${ }^{64}$.

\section{Administrative Provisions}

\section{Pre-Grant Oppositions}

The Indian patent laws also provide more stringent procedures for the obtaining of a patent. Among the strictest of such procedures are those allowing for pre-grant oppositions, which allow any person to file a petition before the concerned patent office opposing a pending patent application ${ }^{65}$. The grounds for the filing of such an opposition are detailed, and cover patentable subject matter ${ }^{66}$, novelty ${ }^{67}$,

6135 U.S.C. $\S 101$

62 KSR v. Teleflex, 550 U.S. 398 (2007)

63 Supra note 47, Section 2(1)

6435 U.S.C. $\S 102(a)$

$65 \mathrm{Id}$, Section 25

66 Id, Section 25(1)(f)

67 Id, Section 25(1) (c), (d) 
obviousness $^{68}$, wrongful obtaining of the invention ${ }^{69}$, insufficient disclosure ${ }^{70}$. The representation for a pre-grant opposition may be filed by any person, and is not limited to interested parties, allowing for the representation of public interest groups and other such parties ${ }^{71}$.

The patent laws of the United States do not presently offer any provisions for pre-grant oppositions. All oppositions that may be raised by a third party must arise after the grant of the patent.

\section{Compulsory Licenses}

Another important administrative procedure allowed for under the Act is the provision of compulsory licenses for the manufacture and export of patented pharmaceutical products to any country having insufficient manufacturing capacity and in order to address public health problems, provided that such compulsory licence or an allowance of importation has been granted by such country ${ }^{72}$.

68 Id, Section 25(1)(e)

69 Id, Section 25(1)(a)

70 Id, Section 25(1)(g), (h)

71 Id, Section 25(1)

72 Id, Section 92A 


\section{Conclusion}

The evolution of patent law within any country must proceed in order to ensure that the patent system is beneficial to its economic interests at every stage in its development. The rapid harmonization of patent laws worldwide, however, is beginning to ensure that countries have little scope for the protection of their economic interests. The objective of every patent system should be the promotion of innovation within its creator country. However, with stronger intellectual property regimes, developing countries may be required to invest in strong IP regimes to protect innovation originating in other countries, with little or no technological benefit accruing to them. While the TRIPS Agreement still allows for some level of flexibility in tailoring patent laws, the international patent regulation scenario is focussed on a shift towards stronger and more harmonised regimes, with the discussions concerning the WIPO's SPLT providing the multilateral push forward, and the incorporation of intellectual property clauses in free trade agreements providing impetus bilaterally.

From the experience of developed countries in their patent histories, it is clear that they have utilized their opportunities to adjust national patent laws to suit their needs at lower stages of development, and that they have benefitted from these opportunities. It is only through the utilisation of these opportunities that countries such as the United States and the European nations have reached a level of technological predominance. However, judging by the experience of developing countries under the TRIPS Agreement and beyond, it appears that this same opportunity may be denied to the countries that need it the most. 